\title{
DINAMIKA INTELEKTUAL ISLAM DI KALIMANTAN SELATAN: Studi Genealogi, Referensi, dan Produk Pemikiran
}

\author{
Rahmadi \\ Jurusan Perbandingan Agama Fakultas Ushuluddin IAIN Antasari \\ Jl. A. Yani Km. 4,5 Banjarmasin Kalsel \\ Diterima 10 Agustus 2011/Disetujui 15 Nopember 2011
}

\begin{abstract}
This paper tries to explore the intelectual Islamic dynamic in South Kalimantan through the studies on many influences that become the genealogic root of Islam in this region, and then through the religious literatures that referenced by the intelectual of religious elite and the tipology of thought's product that emerged for more than two centuries. Here, the writer uses the history of social-intelectual approach with based on the written text. This writing tells us that the genealogical root, intelectual reference, and the tipology of religious thought which was producted actually part of the trend of intelectual muslim dynamic which commonly spreaded in Nusantara and Southeast Asia.
\end{abstract}

Kata kunci: Islam, dinamika intelektual, genealogi, referensi dan pemikiran

\section{Pendahuluan}

Pasca 'penjinakan' tasawuf falsafi model Abdul Hamid Abulung, pada masa Syekh Muhammad Arsyad al-Banjari pada abad ke-18, trend pemikiran Islam memasuki era baru pada abad ke-19, yaitu semakin kokohnya neosufisme yang memiliki perhatian yang tinggi terhadap syariah. Pada abad ini, corak pemikiran Islam hampir sepenuhnya diwarnai oleh ajaran Ahlussunnah Waljamaah. Kencenderungan ini kemudian diperkokoh pada masa berikutnya, di mana sejumlah referensi dan produk pemikiran yang bermunculan pada abad ke-20 digunakan untuk terus memperkokoh corak tersebut dan mempertahankannya sebagai arus utama pemikiran Islam di Kalimantan Selatan. Namun, pada abad ke-20 juga gelombang pembaruan yang melanda wilayah ini menjadi ujian berat terhadap pemikiran arus utama terutama ketika para 'kaum muda' bermunculan dan organisasi keagamaan berhaluan reformis mulai 'menggugat' corak 
pemikiran Islam yang sudah mapan. Gugatan ini tentu saja mendapat perlawanan dari para ulama Banjar 'arus utama' sehingga terjadilah polemik pemikiran di kalangan mereka. Beberapa literatur keagamaan yang ditulis oleh ulama Banjar yang muncul sepanjang abad ke-20 bahkan pada awal abad ke-21 merupakan wujud nyata dari 'perlawanan' terhadap gugatan itu.

Ulasan singkat di atas menunjukkan bahwa terjadi dinamika pada aspek intelektual dalam khazanah keislaman di Kalimantan Selatan terutama pada dua abad terakhir (abad ke-19 dan 20). Di sini terlihat adanya perubahan di samping kesinambungan aspek intelektual, baik berkenaan dengan aspek genealogi, referensi maupun produk intelektualnya. Untuk mengungkap perkembangan intelektualisme Islam inilah tulisan ini disusun.

Pokok persoalan yang dibahas dalam tulisan ini adalah sebagai berikut: (1) Bagaimanakah dinamika intelektual Islam di Kalimantan Selatan dilihat dari aspek genealogi, referensi dan produk pemikiran? dan (2) Bagaimanakah kesinambungan dan perubahan yang terjadi dalam dinamika intelektual Islam di Kalimantan Selatan itu?

Artikel ini merupakan hasil penelitian kepustakaan (library research) yang menggunakan pendekatan sejarah sosial-intelektual ${ }^{1}$ karena objek kajiannya yang berkaitan erat dengan dinamika sejarah intelektual dalam rentang waktu yang cukup panjang dan melibatkan sejumlah produk intelektual dari tokoh-tokoh Islam Banjar yang hidup dalam kurun waktu yang berbeda dengan kondisi sosial-politiknya masing-masing.

Sumber primer tulisan ini adalah sumber-sumber tertulis berupa karya-karya ulama Banjar yang ditulis pada abad ke-18, 19 dan 20 bahkan 21 mulai karya-karya Syekh Arsyad al-Banjari hingga ulama Banjar

\footnotetext{
${ }^{1}$ Sejarah sosial-intelektual sebenarnya merupakan gabungan dari sejarah sosial dan sejarah intelektual. Menuru Helius Syamsuddin, sejarah sosial merupakan sejarah yang mengkaji sejarah masyarakat yang mencakup semua lapisan sosial mulai dari tingkat atas sampai tingkat bawah. Sejarah sosial juga berkaitan dengan sejarah kolektif yaitu sejarah yang mencatat pengalaman sejumlah besar manusia atau unit sosial. Sejarah sosial walaupun tidak menjadikan politik sebagai fokus utamanya tetapi juga tidak jarang juga memasukkan politik ke dalamnya. Sementara Sejarah intelektual merupakan sejarah yang memfokuskan perhatiannya pada alam pikiran manusia pada masa lalu atau diartikan juga sebagai sejarah yang mempelajari ide-ide atau segala yang dicapai oleh akal budi manusia pada masa lampau. Lihat Helius Sjamsuddin, Metodologi Sejarah, (Yogyakarta: Ombak, 2007), h. 307-313 dan 327-328
} 
kontemporer termasuk para ulama akademisi. Sumber-sumber ini menyediakan informasi tentang referensi dan produk pemikiran ulama Banjar sepanjang waktu. Sumber-sumber dalam bentuk silsilah atau sanad keilmuan yang dibukukan juga merupakan sumber tertulis penting untuk menggali genealogi intelektual ulama Banjar. Demikian juga dengan buku-buku biografi dan manakib ulama Banjar juga merupakan sumber penting dalam penelitian ini untuk menggali genealogi intelektual ulama Banjar.

Sumber sekunder tulisan ini berupa sumber-sumber tertulis atau sumber kepustakaan berupa buku-buku yang berkaitan dengan tulisan ini. Demikian juga dengan hasil-hasil penelitian, makalah-makalah seminar dan artikel-artikel ilmiah pada berbagai jurnal yang relevan dengan topik artikel ini.

Tahapan penulisan ini adalah sebagai berikut: (1) mengusut semua evidensi atau sumber (heuristika) yang relevan dengan topik kemudian membuat catatan tentang apa saja yang dianggap penting dan relevan dengan topik, (2) mengevaluasi secara kritis semua evidensi yang telah dikumpulkan (kritik sumber), dan (3) menyusun hasil-hasil penelitian ke dalam suatu pola atau sistematika tertentu, kemudian menafsirkan dan menyajikannya secara deskriptik-analitik.

\section{Genealogi Intelektual}

Terdapat beberapa pengaruh yang memiliki pengaruh besar dan menjadi akar dari formasi intelektualisme di kalangan elite muslim Banjar. Pengaruh-pengaruh itu secara makro adalah sebagai berikut. Pertama, pengaruh Jawa dan Aceh (abad ke-16 dan 17). Pengaruh Jawa memengaruhi corak keislaman masyarakat Banjar pada awal abad ke-16. Pengaruh Jawa (Demak dan Giri) pada saat itu telah mewarnai paham dasar keagamaan masyarakat Banjar, yaitu prinsip-prinsip dasar akidah Ahlussunnah walJamaah, fiqih Syafi'i dan tasawuf akhlaqi. ${ }^{2}$ Pada abad ke-17, pengaruh Jawa ini kemudian tergeser digantikan oleh pengaruh Aceh yang pada saat itu tengah dilanda polemik mengenai ajaran wujudiyah (tasawuf falsafi) yang kontroversial antara pengikut Hamzah Fansuri dengan al-Raniri.

${ }^{2}$ M. Suriansyah Ideham, et. al., (eds.), Sejarab Banjar, (Banjarmasin: Badan Penelitian dan Pengembangan Daerah Propinsi Kalimantan Selatan, 2007), Cet. ke-3, h. 183. 
Pengaruh Aceh dapat dilihat dari beberapa indikasi. Pertama, salinan beberapa Kitab yang diklaim sebagai kitab Barencong menyebut beberapa nama ulama Aceh yang hidup pada abad ke-16 dan 17 serta adapula yang menyajikan karya-karya mereka. Istilah "barencong" sendiri dapat dihubungkan dengan kata rencong (senjata khas Aceh) atau tanah rencong (nama lain dari Aceh) walaupun cerita rakyat Banjar memaknainya sebagai kencong. Kedua, indikasi pengaruh Aceh dapat dilihat pada beberapa pernyataan Syekh Muhammad Arsyad al-Banjari (selanjutnya: al-Banjari). Pada kitab Sabil al-Mubtadin, al-Banjari menyebutkan bahwa dia banyak menemukan salinan-salinan naskah Shirath al-Mustaqim karya al-Raniri yang telah mengalami distorsi. Selanjutnya, pada kitab Tuhfah al-Raghibin, alBanjari membagi kelompok wujudiyyah menjadi dua, yaitu wujudiyah muwabhid dan wujudiyyah mulhid. Pembagian paham wujudiyyah seperti ini mirip dengan yang dilakukan oleh al-Raniri. Beberapa bukti ini menunjukkan bahwa pemikiran dan karya al-Raniri telah menyebar di kalangan masyarakat Banjar pada abad ke-18.

Kedua, pengaruh Haramain. Pengaruh Haramain merupakan pengaruh utama yang membentuk formasi intelektualisme Islam di Kalimantan Selatan sekaligus menjadi faktor pendorong utama meningkatnya dinamisasi intelektual di kalangan elite muslim Banjar. Tidaklah mengherankan jika corak pemikiran, literatur atau referensi keagamaan, serta kiblat keilmuan yang muncul pada abad ke-18 hingga abad ke-20 memperlihatkan dengan jelas pengaruh besar Haramain di dalamnya. Hampir semua silsilah (genealogi) keilmuan atau sanad keilmuan yang berkembang di pesantren tradisional misalnya selalu menyebutkan ulama Haramain di dalamnya.

Harus segera ditekankan bahwa pengaruh Haramain yang melandasi intelektualisme Islam di kalangan masyarakat Banjar berpijak pada doktrin Ahlussunnah Waljamaah yang berseberangan dengan pemahaman Wahhabisme yang juga berkembang di Haramain. Walaupun Wahhabisme sudah eksis sejak masa al-Banjari, sepanjang abad ke-18 hingga abad ke19, Wahhabisme belum menarik hati penuntut ilmu asal Banjar. Baru pada awal abad ke-20, gerakan pemurnian dari kelompok Wahhabi (puritanisme) melanda wilayah Kalimantan Selatan. Kehadiran paham wahhabi yang bersamaan dengan gerakan pembaruan (modernisme) baik yang 
digerakkan oleh individu, organisasi keagamaan maupun melalui jalur pendidikan (madrasah) pada dekade kedua dan ketiga awal abad ke-20 menimbulkan ketegangan, konflik keluarga, polemik pemikiran dan bahkan tindakan kekerasan di masyarakat. Kondisi ini membelah kubu muslim Banjar menjadi dua, yaitu mereka yang dilabeli kaum muda dan mereka yang dilabeli kaum tua/lama. Perlu digarisbawahi pula bahwa walaupun gerakan puritanisme dan modernisme melanda kawasan ini sejak awal abad ke-20, namun arus utama pemikiran Islam di kalangan ulama dan masyarakat Banjar tetap berkiblat pada para ulama Haramain nonwahhabi.

Ketiga, pengaruh intelektual al-Banjari dan keturunannya (abad ke19 hingga kini). Pengaruh al-Banjari dan keturunannya merupakan bagian dari kesinambungan dan perpanjangan dari pengaruh Haramain. Pengaruh Aceh yang selama ini mendominasi wacana intelektual Islam Banjar pada abad 18 mulai tergantikan setelah kedatangan al-Banjari disusul dengan lahirnya sejumlah karya-karya intelektualnya pada akhir abad ke-18. Pengaruh al-Banjari mulai kuat dan dominan dalam membentuk intelektualisme Islam Banjar pada abad ke-19 tidak hanya melalui karyakarya intelektualnya tetapi juga melalui keturunannya.

Salah satu faktor penting dari beredar luasnya pemikiran dan karya intelektual al-Banjari adalah faktor diaspora keturunannya yang berlangsung sejak awal abad ke-19. Keturunan al-Banjari yang tersebar di Nusantara, Asia Tenggara hingga Timur Tengah turut serta membawa karya-karya alBanjari bahkan mengajarkannya di manapun mereka berada.

Keturunan al-Banjari juga tampil menjadi ulama terkemuka di kawasan Kalimantan Selatan sejak abad ke-19. Keturunan al-Banjari di samping mewarisi pemikiran al-Banjari banyak diantara mereka juga merupakan alumni Haramain seperti al-Banjari. Mereka memiliki peran besar dalam mendorong dinamisasi intelektualisme Islam di kawasan Kalimantan Selatan disamping meneruskan warisan pemikiran al-Banjari.

Keempat, pengaruh kaum Alawiyyin (ulama Hadhrami). Diduga kaum Alawiyyin telah hadir di kawasan Kalimantan Selatan sejak era awal kerajaan Islam Banjar. Hanya saja sedikit sekali informasi yang dapat menjelaskan peran mereka dalam pembentukan intelektual Islam di kalangan masyarakat Banjar pada fase awal. Ada spekulasi yang menyebutkan bahwa Khatib Dayan yang diutus untuk mengislamkan raja Banjar adalah orang Arab 
dari kalangan ahlul bait yang bernama Sayyid Abdurrahman. Ada pula yang menduga dia adalah orang Jawa keturunan Arab (bisa diduga Arab dari kalangan Alawiyyin). ${ }^{3}$

Kontak dan interaksi ulama Banjar dengan kaum Alawiyyin terjadi di beberapa tempat. Tempat pertama adalah Haramain. Sejak abad ke-18 hingga abad ke-20 ulama Banjar yang menuntut ilmu di Haramain belajar kepada para syekh yang sebagiannya berasal dari kalangan Alawiyyin. Ulama Alawiyyin yang ada di sini ada yang datang dari Hadramaut dan ada juga yang datang dari wilayah lain.

Tempat kedua adalah kawasan Nusantara sendiri. Kawasan Nusantara sendiri merupakan salah satu tempat tujuan migrasi dari kaum Alawiyyin. Mereka secara bergelombang berpindah dari Hadramaut ke berbagai daerah di Nusantara. Sejumlah ulama Banjar menjalin relasi gurumurid dan persahabatan dengan kaum Alawiyyin ini di berbagai kawsan di Nusantara termasuk di Kalimantan Selatan sendiri.

Pada abad ke-19, pengaruh kaum Alawiyyin Nusantara terhadap masyarakat Banjar belum terlihat jelas. Ini disebabkan penelitian ini belum menemukan informasi mengenai hal itu. Dari indikasi yang ada, salah satu ulama dari kaum Alawiyyin pada akhir abad ke-19 yang karya dan pengaruhnya sampai pada masyarakat Banjar adalah Sayyid Utsman Yahya al-Batawi pengarang sifat 20 yang banyak dikaji oleh masyarakat Banjar hingga kini.

Pada abad ke-20, pengaruh kaum Alawiyyin ini semakin besar. Peningkatan pengaruh kaum Alawiyyin terhadap corak keislaman masyarakat Banjar dapat dilihat dari beberapa indikasi berikut: (1) Meningkatnya pembacaan kitab-kitab maulid di kalangan masyarakat Banjar; (2) Meningkatnya relasi dan kontak keilmuan dengan para sayyid dan habaib termasuk yang berasal dari Haramain dan Hadramaut; (3) Meningkatnya penerbitan dan pembacaan kitab manakib kalangan ahlul bait yang dilakukan oleh ulama Banjar; (4) Meluasnya penyebaran tarikat Alawiyyah di kalangan masyarakat Banjar; (5) Tradisi amaliah kalangan Alawiyyin seperti pembacaan ratib al-Attas, Ratib al-Haddad, Dala'il, dan sebagainya masih terus bertahan di kalangan muslim Banjar; (6) Sejumlah karya-karya ulama Hadramaut terutama karya intelektual al-Haddad

\footnotetext{
${ }^{3}$ Lihat Suriansyah Ideham, et. al. (eds), Sejarah Banjar, h. 95.
} 
menjadi bagian dari referensi intelektual Islam yang masih terus dibaca dan dipelajari baik kalangan terdidik maupun awam.

Tempat ketiga adalah Hadramaut, negeri leluhur ulama Hadrami dari kalangan Alawiyyin. Pada akhir abad ke-20, Hadramaut (Tarim) mulai dilirik oleh santri terpelajar sebagai tujuan studi. Dipilihnya Hadramaut, selain karena faktor genealogi intelektual yang telah tercipta sebelumnya tetapi juga tradisi pemikiran dan praktik keagamaan masyarakat Banjar sering kali sejalan dan mendapat dukungan dari kaum Alawiyyin ini.

Kelima, pengaruh Mesir (al-Azhar). Pengaruh Mesir, terutama para ulama al-Azhar, telah menjadi bagian dari pembentukan intelektualisme Islam Banjar sejak lama melalui Haramain. Hanya saja pada abad ke-18 dan 19 tidak ada satupun ulama Banjar yang pernah belajar langsung di Mesir. Baru pada awal abad ke-20 salah seorang ulama Banjar yang bernama Abdurrasyid (1885-1934) menjadi orang Banjar pertama yang menempuh studinya di al-Azhar (1912-1922). Setelah kembali ke Amuntai, ia menjadi motivator dan inspirator bagi sejumlah kelompok muslim terpelajar untuk studi di al-Azhar (Mesir). Pada paruh pertama abad ke-20, sejumlah mahasiswa Banjar telah berhasil menyelesaikan studi mereka di al-Azhar seperti Juhri Sulaiman (masa studi 1922-1931), Mansyur Ismail (masa studi 1925-1932), Abdul Hamid Karim (masa studi 1929-1932), Muhammad As'ad (studi di al-Azhar sekitar tahun 1930-1933), Abdurrahman Ismail (masa studi 1929-1947), Mastur Jahri (masa studi 1940-1949) dan masih ada beberapa lagi.

Peralihan orientasi studi kalangan terpelajar muslim Banjar dari Haramain ke Mesir (al-Azhar) sedikit banyaknya dipengaruhi oleh munculnya Mesir sebagai pusat pembaruan Islam pada masa itu. Kemungkinan besar keberangkatan Abdurrasyid ke Mesir didorong oleh salah seorang gurunya yang bernama Jafri bin Umar (w. 1931 M) yang sejak kepulangannya dari Mekkah pada tahun 1897 terpengaruh oleh ide-ide pembaruan di Mesir. Masa studi Jafri bin Umar di Mekkah antara 18921897 merupakan masa di mana ide pembaruan Muhammad Abduh (w. 1905 M) sedang hangat. Tampaknya ide pembaruan di Mesir tersebar sampai di Haramain dan merupakan transit beredarnya ide pembaruan menuju Nusantara melalui para penuntut ilmu dan para haji. Memang belum diketahui sejauhmana ide pembaruan merasuk di kalangan mahasiswa 
Banjar ketika studi di Mesir. Kesulitan untuk mengetahui hal ini disebabkan tidak ada karya intelektual para alumni awal al-Azhar ini berupa tulisan yang dapat dijadikan dasar untuk mengetahui respon mereka terhadap ideide pembaruan di Mesir.

Keenam, pengaruh gerakan pembaruan dan pemurnian (abad ke-20). Masuknya gerakan dan pemikiran pemurnian (salafisme puritan) dan pembaruan (modernisme) ke Kalimantan Selatan bersumber dari berbagai arus pemikiran, yaitu pengaruh Haramain, Mesir (al-Azhar), dan pengaruh gerakan pembaruan yang berkembang di Sumatera dan Jawa. Di atas telah dikemukakan tentang pengaruh Haramain dan pengaruh al-Azhar dalam pembentukan intelektualisme Islam masyarakat Banjar. Kedua pengaruh ini memiliki andil yang besar dalam melahirkan pemikiran dan gerakan pemurnian dan pembaruan di kalangan masyarakat Banjar. Gerakan pemurnian lebih banyak dipengaruhi oleh gerakan Wahhabi yang berkembang di Haramain sementara gerakan pembaruan (modernisme) banyak dipengaruhi oleh gerakan pembaruan yang berkembang di Mesir.

Di samping pengaruh langsung dari Timur Tengah, gerakan pembaruan yang berkembang di Sumatera dan Jawa turut ikut mendorong berkembangnya gagasan dan gerakan pemurnian dan pembaruan Islam di Kalimantan Selatan pada dekade 1920-an dan 1930-an . Pengaruh Sumatera pada umumnya tersalur melalui sejumlah majalah seperti al-Munir (Minangkabau), al-Munir el-Manar (Padang Pajang) dan al-ittifaq wal Iftiraq (Padang). Pengaruh Jawa lebih banyak tersalur melalui sejumlah organisasi keagamaan yang berhaluan pembaharuan seperti Muhammadiyah, Syarikat Islam, Persis dan ditambah dengan hadirnya buku kaum reformis seperti buku Hamka dan A. Hassan.

Eksistensi dan kemunculan gerakan pemurnian dan pembaruan di kawasan Kalimantan Selatan pada awal abad ke-20 tidak terlepas dari beberapa faktor. Pertama, kembalinya sejumlah penuntut ilmu dan ulama asal Banjar dari Haramain dan Mesir. Mereka ini ada yang terpengaruh dengan gerakan Wahabi dan ada pula yang terpengaruh dengan gagasan pembaruan yang berkembang di Mesir seperti gagasan pembaruan Muhammad Abduh. Kedua, para pedagang yang melakukan perdagangan antarpulau ke Jawa dan Sumatera dan para pedagang yang pulang-pergi Banjarmasin-Hulu Sungai turut membantu tersebarnya gerakan-gerakan 
ini ke berbagai kawasan di Kalimantan Selatan. Ketiga, beredarnya majalahmajalah dan buku-buku yang berisi gagasan-gagasan pemurnian dan pembaruan yang dibawa oleh para ulama dan pedagang yang memiliki usaha dagang antarpulau. Keempat, Hadir dan berkembangnya sejumlah organisasi keagamaan yang berhaluan pemurnian dan pembaruan seperti Sarikat Islam, Muhammadiyyah dan lainnya. Kelima, Berdirinya sejumlah lembaga pendidikan Islam berhaluan pembaruan.

\section{Referensi Intelektual}

Salah satu faktor penting dinamisasi intelektualisme Islam di Kalimantan Selatan adalah hadirnya sejumlah literatur keagamaan yang dijadikan sebagai referensi intelektual kalangan elite muslim di Kalimantan Selatan sejak abad ke-18. Referensi intelektual itu dapat dikelompokkan sebagai berikut.

1. Karya intelektual ulama Timur Tengah

Kehadiran kitab-kitab yang merupakan karya ulama Timur Tengah secara signifikan dimulai dengan kembalinya al-Banjari dengan membawa sejumlah kitab yang dipelajarinya di Haramain. Kitab itu ada yang dibelinya dan adapula yang hasil dari salinannya. Berkaca dari sejumlah referensi yang digunakan oleh al-Banjari, dapat dilihat bahwa kitab-kitab fiqih Syafiiyyah seperti al-Nihayah, Minhaj, al-Wajiz, al-Mahalli, Ghayah wa alTaqrib, Fath al-Jawad, Majmu', dan sebagainya telah beredar secara terbatas di kalangan elite muslim seperti al-Banjari. Pada aspek akidah, kitab-kitab tauhid seperti Syarh Jawharah al-Tawhid, Umdah al-Murid, Aqidah al-Tahawiyah dan lainnya telah dimiliki oleh elite muslim Banjar. Demikian pula dalam bidang tasawuf, karya sufi seperti Ithaf al-Sadab (syarh Ibya), Minhaj alAbidin, 'Awarif al-Ma'arif bahkan Futuhat al-Makkiyah telah dikaji oleh elite muslim Banjar.

Pada abad ke-19 karya intelektual ulama Timur Tengah yang dibawa alumni Haramain semakin banyak. Referensi intelektual yang ada merupakan kesinambungan dari referensi intelektual yang berkembang pada abad ke-18, ditambah dengan karya intelektual ulama Haramain yang hidup pada abad ke-19 seperti karya-karya Syekh Ahmad Dimyathi, Syekh Ahmad Zaini Dahlan dan Syekh Sayyid Bakri Syaththa. 
Pada abad ke-20, karya ulama Timur Tengah yang menjadi referensi intelektual semakin luas dan variatif. Di kalangan ulama tradisional berkembang kitab-kitab mu’tabarah dalam bidang fiqih, tauhid dan tasawuf serta ilmu bahasa dari karya intelektual ulama Timur Tengah dari zaman pertengahan Islam hingga karya intelektual yang terbit pada era modern. Masuknya gerakan pembaharuan di Kalimantan Selatan dan munculnya sejumlah pesantren modern memunculkan referensi intelektual baru di kalangan elite muslim Banjar baik klasik (karya Ibn Rusyd, Ibn Taimiyah, Ibn al-Qayyim al-Jawzi dan Muhammad Abd al-Wahhab) maupun modern (terutama karya sejumlah ulama Mesir modern seperti Muhammad Abduh, Rasyid Ridha, al-Maraghi, dan lainnya). Kehadiran sejumlah alumni al-Azhar dan munculnya perguruan tinggi Islam di Kalimantan Selatan meningkatkan secara drastis kehadiran karya intelektual ulama Timur Tengah kontemporer seperti karya al-Qardhawi, Sayyid Sabiq, Abd alHalim Mahmud, Mahmud Syaltut dan lainnya.

2. Karya intelektual ulama Asia Tenggara (Nusantara)

Karya ulama Asia Tenggara yang banyak dijadikan referensi intelektual pada abad ke-18 adalah karya al-Raniri seperti Shirath alMustaqim. Karya intelektual al-Falimbani dan al-Fathani diduga kuat juga banyak beredar di kalangan elite muslim Banjar pada abad ke-19. Apalagi pada akhir abad ke-19, karya intelektual kedua ulama ini dicetak di beberapa penerbitan. Karya intelektual Nawawi al-Bantani juga telah menjadi referensi intelektual mengingat sejumlah ulama Banjar pernah belajar kepadanya di Haramain pada akhir abad ke-19. Pada abad ke-20, karya intelektual ulama Asia Tenggara semakin banyak digunakan. Selain karya al-Falimbani, al-Fathani dan al-Bantani, ulama lain yang karyanya dijadikan referensi intelektual adalah Syekh Yasin al-Fadani, Abdul Qadir al-Mandili, Dahlan al-Kadiri, dan Umar Baraja.

3. Karya intelektual ulama Banjar

Pada abad ke-18, literatur keagamaan yang menjadi referensi intelektual penting yang berasal dari karya ulama Banjar adalah karya intelektual al-Banjari dan Nafis al-Banjari. Pada abad ke-19, seiring menyebarnya karya al-Banjari dan Nafis al-Banjari, muncul pula beberapa literatur keagamaan menjadi referensi intelektual yaitu karya intelektual 
Mufti Jamaluddin dan Muhammad Thayyib al-Banjari. Pada akhir abad ke-19 muncul beberapa karya Husin Kedah (keturunan al-Banjari) dan Abdurrahman Nagara. Tetapi tampaknya karya keduanya tidak menyebar luas di kalangan masyarakat Banjar sehingga kurang dikenal.

Pada abad ke-20 muncul sejumlah ulama yang karya intelektualnya sering menjadi referensi intelektual baik di pengajian maupun di pesantren. Mereka di antaranya adalah Abdurrahman Shiddiq, Muhammad Kasyful Anwar, Muhammad Khalid Tangga Ulin, Asy'ari Sulaiman, Abdurrahman Sungai Banar, Anang Sya'rani, Muhammad Sarnie, Abdul Muthalib Muhyiddin, dan Muhammad Syukri Unus. Beberapa ulama yang produktif menulis seperti Husin Nafarin, Munawwar, Muhammad Nuruddin Marbu dan Ahmad Fahmi Zamzam memiliki karya intelektual yang turut memperkaya khazanah intelektual masyarakat Banjar pada akhir abad ke20 dan awal abad ke-21.

\section{Produk Intelektual}

Dalam tulisan ini, produk pemikiran yang dihasilkan oleh elite muslim Banjar melalui karya intelektual mereka diklasifikasikan dalam beberapa model pemikiran secara tipologis. Untuk efisiensi, produk pemikiran yang dikemukakan dibatasi pada tiga disiplin keislaman, yaitu pemikiran tauhid (akidah atau kalam), pemikiran fiqih dan pemikiran tasawuf.

Secara tipologis, terdapat beberapa model pemikiran tauhid yang telah dihasilkan. Pertama, pemikiran tauhid model heresiologi. Pemikiran semacam ini muncul pada akhir abad ke-18 yang berasal dari al-Banjari yang terdapat dalam Tuhfah al-Raghibin. Pemikiran tauhid al-Banjari ini merupakan corak pemikiran yang cenderung "hitam putih" dan kritis terhadap berbagai aliran di luar Ahlusssunnah waljamaah dan berbagai tradisi lokal masyarakat Banjar yang berkembang pada masanya. Kedua, pemikiran tauhid model sifat 20 yang telah berkembang sejak abad ke-19 hingga abad ke-20. Pemikiran model ini berbasis pada model formulasi tauhid Sanusiyyah yang berinduk pada teologi Asy'ariyyah. Wacana dominan yang dikemukakan dalam berbagai literatur tauhid yang ditulis oleh ulama Banjar berisi berbincangan mengenai sifat Allah dan sifat rasul serta unsur-unsur 'aqa id yang menjadi kandungan dua kalimat syahadat. 
Pada abad ke-19 kensep sifat 20 belum begitu terlihat dalam karya ulama Banjar. Baru pada abad ke-20 perbincangan mengenai sifat 20 secara jelas dapat dilihat melalui sejumlah karya tauhid ulama Banjar. ${ }^{4}$ Ketiga, pemikiran tauhid model rukun iman. Pemikiran tauhid pada model ini cenderung memberikan porsi yang lebih berimbang pada masing-masing rukun iman. Hanya saja, tidak banyak karya ulama Banjar yang memuat pembahasan tentang rukun iman secara berimbang dan tidak lagi diberatkan pada uraian mengenai sifat Allah dan rasul saja. Keempat, pemikiran tauhid model aliran kalam. Model pemikiran seperti ini sebenarnya sudah muncul sejak abad ke-18 melalui karya al-Banjari dan berlanjut hingga abad ke-20. Namun sebagiannya tidak netral dan cenderung 'menghakimi' aliran yang lain. Baru pada paruh kedua abad ke-20 perbincangan tentang aliran Kalam cenderung lebih lunak dan netral terhadap berbagai aliran Kalam. Kelima, model pemikiran tauhid yang lebih menekankan pengaruh iman terhadap pembangunan karakter dan moral. Pemikiran semacam ini muncul pada akhir abad ke-20 yang digagas oleh kalangan akademisi perguruan tinggi Islam. Karya tauhid mereka lebih menonjolkan formulasi tauhid yang lebih sederhana dan mengedepankan aspek implikasi moral dari ajaran tauhid. Kelima, model pemikiran berbasis al-Asma` al-Husna. Di sini 99 asma Allah difungsikan sebagai media mengenal Allah sekaligus difungsikan untuk membangun karakter muslim.

Produk pemikiran fiqih secara tipologis setidaknya dapat dikategorikan menjadi empat model. Pertama, fiqih praktis. Pemikiran ulama Banjar di bidang fiqih lebih banyak berisi ulasan tentang masalah fiqih secara praktis

${ }^{4}$ Pada abad ke-19, Parukunan Jamaluddin telah memuat 13 sifat Allah secara singkat dan paruh kedua abad ke-19, muncul Miftah Jannah (1832 atau 1839) karya Muhammad Thayyib alBanjari yang telah menyebutkan sifat 20 secara lengkap dan menjadikan Umm al-Barabin dan kifayah al-Awam sebagai referensinya. Kemudian, risalah tauhid karya ulama Banjar yang diterbitkan sepanjang abad ke-20 di antaranya adalah 'Aqa id al-Iman (1920) karya Abdurrahman Shiddiq al-Banjari, 'Aqidah al-Iman (1925) karya Muhammad Khalid, Risalab Sifat Dua Puluh (Kalimah al-Najah fi Ushuluddin) (1353/1935 M) karya Muhammad Ramli, al-Durr al-Farid (1354/ 1936) karya Muhammad Kasyful Anwar, Ibtida` al-Tawbid (1937) karya Abdul Qadir Noor, Siraj al-Mubtadi'in (1939) karya Sulaiman Asy'ari, Risalab Hidayab al-Mubtadiin (1371/1952) karya Muhammad Sarni, Tubfah al-Ikhwan (1372/1953) karya Muhammad Sarni, Kifayat al-Mubtadi in (1374/1955 M) karya Abdurrahman bin Muhammad Ali, Risalab Tashil al-Muta'allim (1390 H/ 1970) karya Ma'shum Mukhtar, Risalah Pelajaran Ilmu Taubid (1980) karya Jafri bin Utuh, dan Risalab Taubid Mengenal Allab (1983) karya Abdul Hamid. 
dan aplikatif. Secara umum, model fiqih praktis ini lebih banyak membahas tentang masalah fiqih ibadah. Sisanya berkenaan dengan fiqih waris (fara'idh), fiqih nikah, dan penyelenggaraan jenazah. Dalam hal ini terdapat beberapa model penulisan fiqih praktis ini, yaitu model parukunan (paling praktis untuk orang awam), model fiqih ibadah, dan model Sabilal yang lebih kompleks dan komparatif (lebih ditujukan untuk kalangan elite). Kedua, fiqih polemis (ikhtilaf). Pemikiran fiqih polemis mulai muncul pada awal abad ke-20 sebagai respon terhadap gerakan pemurnian (salafisme) dan pembaruan (modernisme) yang tumbuh dan berkembang di Kalimantan Selatan. Berikutnya fiqih model ini muncul sebagai respon terhadap masalah-masalah fiqhiyyah aktual yang terjadi di kalangan masyarakat. Kitab fiqih yang termasuk fiqih polemis di antaranyanya adalah Risalah Himayah al-Ikhwan 'an Wuqu' fi al-Dhalal wa al-Tughyan (1928), Tanqih al-Nuwah (1931), al-Dzakbirah al-Tsaminah (1967), dan Ayyuha al-Kiram Darf Dhufuf fi al-Masjid Haram (2001). Ketiga, pemikiran fiqih model fiqih sufistik. Pemikiran fiqih model ini lebih banyak mengupas masalah rahasia ibadah atau sisi batiniah ibadah dengan pendekatan sufistik. Pemikiran fiqih model ini dapat dilihat pada karya Abdurrahman Shiddiq (Asrar al-Shalah) dan Muhammad Syukri Unus (Asrar al-Shawum). Keempat, pemikiran fiqih model fatwa. Pemikiran fiqih model ini merupakan hasil dari jawaban tertulis ulama Banjar yang dikonsultasikan kepadanya kemudian dikumpulkan dan diterbitkan menjadi buku. Contoh karya fiqih model ini adalah Ibanatul Abkam karya Ahmad Bakeri.

Produk pemikiran tasawuf yang berkembang di Kalimantan Selatan secara tipologis adalah (1) pemikiran model tasawuf falsafi (ajaran wujudiyyah), (2) neosufisme, dan (3) pemikiran tasawuf sunni bercorak akhlaki-amali yang melepaskan diri sepenuhnya dari tasawuf falsafi. Ajaran tasawuf falsafi (wujudiyyah) yang berkembang di Aceh diduga kuat telah masuk ke wilayah tanah Banjar pada abad ke-17 dan tetap berpengaruh kuat pada awal abad ke-18. Ajaran Wujudiyyah ini tampaknya mulai terdesak dengan kehadiran karya-karya al-Raniri dan kemudian disusul dengan karyakarya al-Banjari terutama Tuhfah al-Raghibin yang menentang ajaran wujudiyyah mulhid. Sebaliknya, al-Banjari mendukung ajaran wujudiyyah muwabhid. 
Pada abad ke-19, beredar kitab Fath al-Rabman karya Zakariya alAnshari dan al-Durr al-Nafis. Kedua kitab ini berisi ajaran tasawuf dengan menggunakan perspektif tauhid (tauhid af'al, asma, sifat dan zat). Fath alRahman merupakan kitab tasawuf yang disebarkan dan diajarkan oleh keturunan al-Banjari. Sementara al-Durr al-Nafis tidak diragukan diajarkan oleh Muhammad Nafis sendiri. Pada abad ke-20, al-Durr al-Nafis dan secara tidak langsung juga menimpa Amal Ma'rifah dikritik sebagai ajaran tasawuf falsafi yang mengandung ajaran tasawuf wahdatul wujud Ibnu Arabi. Ini membuat beberapa ulama melarang kitab ini digunakan di pengajian pada awal abad ke-20. Polemik tentang kitab ini terus berlangsung hingga awal abad ke-21. Sejumlah ulama Banjar menilai al-Durr al-Nafis sebagai kitab yang mengandung ajaran Jabariyah, wahdatul wujud, hulul, dan filsafat yang sesat. Di dalamnya juga terdapat ta'arudh (kontradiksi) dan khatha' (kesalahan) yang tidak dapat ditakwilkan.

Di samping adanya tasawuf falsafi dan kritik tehadapnya, muncul pula neosufisme yaitu pemikiran tasawuf sunni yang berusaha melakukan rekonsiliasi antara sufisme al-Ghazali dan sufisme Ibnu Arabi (antara sufisme akhlaqi dan sufisme wujudiyyah) atau secara lebih luas sintesis antara sufisme dan formalisme syari'ah. Pada akhir abad ke-18, neosufisme nulai mengakar melalui pengaruh al-Raniri dan al-Banjari. Neosufisme alBanjari lebih menonjolkan formalisme syari'ahnya daripada sisi sufismenya, sementara Nafis lebih menonjolkan sisi sufisme wujudiyyahnya daripada formalisme syari'ahnya. Karena itu, neosufisme al-Banjari lebih menonjol dibanding Nafis al-Banjari. Pada abad ke-19 dan abad ke-20, karya-karya al-Falimbani turut memperkuat trend neosufisme yang telah dirintis oleh al-Banjari. Dalam dua buah karya tasawufnya, Siyar al-Salikin dan Hidayah al-Salikin, al-Falimbani berhasil memperkokoh trend neosufisme dan memberikan porsi berimbang yang lebih dominan dibanding karya alBanjari yang lebih menonjolkan formalisme syariah.

Pada abad ke-20, ajaran sufisme al-Ghazali semakin kokoh dan begitu dominan di kalangan masyarakat Banjar. Beberapa ulama Banjar menulis beberapa risalah tasawuf yang dipengaruhi atau diambil dari sufisme alGhazali seperti Risalah Tafakkur (1939) karya Muhammad Khalid yang isinya dipengaruhi oleh ajaran al-Ghazali tentang tafakkur dalam Ibya. Adapula Mabadi 'Im al-Tasawuf (1973) karya Muhammad Sarnie yang 
banyak mengutip atau bahkan menerjemah secara ringkas kitab Bidayah alHidayah karya al-Ghazali.

Dominasi sufisme al-Ghazali dalam karya-karya ulama Banjar pada abad ke-20, tidak dapat dijadikan sebagai indikator bahwa ajaran tasawuf falsafi telah ditinggalkan. Dominasi sufisme al-Ghazali sebenarnya hanya mendominasi 'di permukaan' sementara sufisme yang dipengaruhi Ibn Arabi berada di bagian 'dalam' dan menjadi kajian elitis dan ekslusif. Muhammad Syukri Unus, misalnya, ulama yang banyak mengkaji dan mengajarkan karya-karya al-Ghazali, juga mempelajari kitab al-Durr al-Nafis pada salah seorang gurunya di Martapura yaitu Ahmad Royani (w. 1417). Dia juga mentashih dan mengkaji kitab al-Durr al-Nafis dan 'Amal Marifah kepada Syarwani Abdan Bangil (w.1989) atas anjuran Guru Ijai. Karena itu, tidak mengherankan ketika al-Durr al-Nafis dikritik dan dilarang oleh beberapa ulama Banjar, dia justru membelanya dan mengatakan bahwa kitab al-Durr al-Nafis merupakan ajaran tasawuf tingkat tinggi.

Salah satu indikator yang dapat digunakan untuk mengidentifikasi penganut neosufisme adalah adanya pengakuan akan adanya strata kitab tasawuf yang dipelajari yang biasanya dibagi tiga, yaitu tingkat mubtadi (biasanya beberapa karya al-Ghazali dan al-Haddad), tingkat mutawassit (biasanya kitab Hikam), dan tingkat muntahi (biasanya adalah karya ibn Arabi). Ulama Banjar yang mengikuti pemikiran al-Falimbani (terutama kitab Sair al-Salikin-nya) termasuk kategori ini.

Pada abad ke-20 juga menandai munculnya trend pemikiran sunni yang melepaskan diri sepenuhnya kepada ajaran tasawuf falsafi. Kalangan ulama atau elite muslim kalangan akademisi yang masuk kategori ini biasanya adalah mereka yang bersikap kritis dan menolak ajaran tasawuf falsafi terutama berkenaan dengan ajaran wahdatul wujud, hulul, ittihad, ittishal dan lainnya. Mereka menilai ajaran ini bukan murni Islam tetapi berasal dari unsur-unsur di luar Islam (filsafat Yunani, Kristen, Hindu, Budha, Zoroaster dan lainnya). Ada juga yang menolak tasawuf falsafi dengan menggunakan perspektif teologi. Mereka menganggap tasawuf falsafi seperti al-Durr al-Nafis mengandung ajaran Jabariyyah yang sesat.

Ciri pandangan tasawuf sunni yang melepaskan diri dari ajaran tasawuf falsafi di antaranya adalah: (1) menegaskan perbedaan antara khaliq dan hamba; (2) sumber tasawuf berdasarkan Alquran, hadis, amaliah 
sahabat dan tabiin tanpa memberikan perluasan secara spekulatif-filosofik; (3) konsep maqam dan abwal bagi mereka merupakan bentuk dari amal salih dan akhlak yang tinggi; dan (4) karamah dan ma'unah bukan merupakan tujuan dan perhatian dari sufi, (5) para sufi yang dianggap sebagai tokoh intelektual tasawuf sunni adalah Hasan Baseri, Haris al-Muhasibi, Junaid al-Baghdadi, al-Ghazali, dan al-Haddad, (6) mereka menganjurkan mengkaji kitab tasawuf mu'tabarah seperti Maraqi al-Ubudiyyah, Risalah al-Mu'awanah, Kifayah al-Atqiya, Minhaj al-Abidin, Ihya Ulum al-Din dan Penawar Bagi Hati (bahasa Melayu) serta melarang mengkaji kitab-kitab tasawuf falsafi seperti al-Durr al-Nafis dan sejenisnya.

\section{Penutup}

Dinamika intelektual Islam yang berlangsung di Kalimantan Selatan tidak lepas dari dinamika intelektual Islam yang berlangsung di Timur Tengah dan Nusantara secara umum. Sejumlah pengaruh luar telah membentuk intelektualisme Islam di kalangan elite muslim Banjar baik itu pengaruh Timur Tengah (Haramain, Mesir dan Hadramaut) maupun Nusantara sendiri (Aceh dan Jawa). Beberapa pengaruh ini telah masuk sejak abad abad ke-16, yakni pada masa Islamisasi awal masyarakat Banjar. Di samping pengaruh luar, pengaruh internal juga turut memberikan kontribusi besar bagi dinamika intelektual Islam di Kalimantan Selatan dengan hadirnya karya-karya al-Banjari dan keturunannya. Bahkan, karyakarya al-Banjari dan aktivitas keturunannya turut mempengaruhi dinamika intelektual di Nusantara bahkan di Asia Tenggara.

Dinamika intelektual Islam di Kalimantan Selatan dapat pula dilihat dari referensi intelektual yang berkembang di kalangan elite muslim Banjar, pengajian dan lembaga pendidikan Islam (pesantren). Referensi keislaman masyarakat Banjar ternyata secara umum tidak berbeda dengan referensi iintelektual yang berkembang di Nusantara bahkan Asia Tenggara secara umum. Mulai abad ke-18, masyarakat Banjar juga dapat mengkaji sejumlah referensi intelektual yang dikarang oleh ulama Banjar sendiri. Pada abad ke-19, karya ulama Banjar belum meningkat bahkan cenderung menurun. Namun pada abad ke-20 karya ulama Banjar meningkatkan cukup drastis dibanding abad sebelumnya. 
Dinamika intelektual Islam dapat pula dilihat dari produk pemikiran di bidang tauhid, fiqih dan tasawuf yang dihasilkan elite muslim Banjar. Di bidang tauhid, produk pemikiran dan penulisan tauhid yang muncul dapat dipetakan menjadi beberapa model, yaitu model heresiologi, model sifat 20, model rukun iman, model aliran kalam, model pemikiran tauhid yang lebih menekankan pengaruh iman terhadap pembangunan karakter dan moral, dan model pemikiran tauhid berbasis al-Asma' al-Husna. Di bidang fiqih, model pemikiran dan penulisan fiqih yang muncul adalah model fiqih praktis, fiqih polemis, fiqih sufistik, dan model fiqih fatwa. Di bidang tasawuf pemikiran dan penulisan tasawuf yang muncul adalah model tasawuf falsafi, neosufisme dan tasawuf sunniy yang melepaskan diri sepenuhnya dari pengaruh tasawuf falsafi seperti sufisme wujudiyyah dan sejenisnya []

\section{DAFTAR PUSTAKA}

Abdan, M. Syarwani, (2003). al-Dzakhirat al-Tsaminah li Abl al-Istiqamah: Simpanan Berharga Masalah Talqin-Tablil-Tawassul. Bangil: PP. Datuk Kalampayan.

Abdullah, Hawash, (1980). Perkembangan Ilmu Tasawuf dan Tokoh-tokohnya di Nusantara. Surabaya: al-Ikhlas.

Abdullah, H.W. Muhd. Shaghir, (1982). Syeikh Mubd Arsyad al-Banjari Matahari Islam. Mempawah: Pondok Pathanah.

Abdullah, H.W. Muhd. Shaghir, (1990). Syeikh Muhammad Arsyad al-Banjari Pengarang Sabilal Mubtadin. Kuala Lumpur: Khazanah Pathaniyah.

Azra, Azyumardi, (1995). Jaringan Ulama Timur Tengah dan Kepulauan Nusantara Abad XVII dan XVIII: Melacak Akar-akar Pembaruan Pemikiran Islam di Indonesia. Bandung: Mizan.

Azra, Azyumardi, (2002). Islam Nusantara: Jaringan Global dan Lokal. Bandung: Mizan.

Azra, Azyumardi, (1999). Renaissans Islam Asia Tenggara: Sejarah Wacana dan Kekuasaan. Bandung: Remaja Rosdakarya. 
Azra, Azyumardi, (1999). Islam Reformis Dinamika Intelektual dan Gerakan. Jakarta: PT Raja Grafindo Persada.

Basuni, Ahmad, (1941). Djiwa Jang Besar (M. Arsjad Bandjar-Surgi H. Basar Kalampajan). Kandangan: P.B. Musjawaratuthalibin.

Basuni, Ahmad, (1986). Nur Islam di Kalimantan Selatan (Sejarah Masuknya Islam di Kalimantan Selatan). Surabaya: PT Bina Ilmu.

Daudi, Abu, (1996). Maulana Syekh Muhammad Arsyad al-Banjari (Tuan Haji Besar). Martapura: Sekretariat Madrasah Sullamul Ulum Dalam Pagar.

Emroni, (2000). Pembaharuan Pendidikan Islam di Kalimantan Selatan Awal Abad XX (Studi Gerakan Alumni Timur Tengah Terhadap Pembaharuan Pendidikan Islam di Kalimantan Selatan Tabun 1900-1950). Banjarmasin: Puslit IAIN Antasari.

Faridah, Siti dkk, (2008). K.H. Muhammad Nuruddin Marbu al-Banjary alMakkey dan Karya-karyanya. Banjarmasin: Puslit IAIN Antasari.

Haderanie H.N., (t.th.). Ilmu Ketubanan Permata Yang Indah (Ad-Durrunnafis). Surabaya: CV Amin.

Haira, Bahran Noor, dkk., (2008). Ulama Banjar dan Karya-karyanya di Bidang Taubid. Banjarmasin: Puslit IAIN Antasari.

Hamka dan Gusti Abdul Muis, (1985). Meninjau Sejarah Masuk dan Berkembangnya Islam di Kalimantan Selatan. Banjarmasin: Panitia Pembangunan Gedung Sekolah Menengah Putri Muhammadiyah Banjarmasin.

Ideham, M. Suriansyah, et. al., (eds.), (2007). Sejarah Banjar. Banjarmasin: Badan Penelitian dan Pengembangan Daerah Propinsi Kalimantan Selatan.

Mahlan AN., dkk, (1989). Pemikiran-pemikiran Keagamaan Syekh Mubammad Arsyad al-Banjari, laporan penelitian. Banjarmasin: IAIN Antasari.

Makmur, Ahdi, dkk., (1999). Sejarah Perkembangan Nabdlatul Ulama di Kalimantan Selatan (1928-1984). Banjarmasin: Puslit IAIN Antasari. 
Maksum, M. Nur, (2007). Musyawaratutthalibin: Historis, Perjuangan dan Pergulatan Pemikiran. Banjarmasin: Antasari Press.

Masdari, dkk., (2008). Kiprah Keulamaan Tuan Guru H. Mubammad Syarwani Abdan (Guru Bangil). Banjarmasin: Puslit IAIN Antasari.

Munawwar, (t.th.). Nûr al-Abshâr fì Dzìkr Nubdzat min Manâqib al-Syaykh Mubammad Kasyful Anwar. Martapura: Majelis Taklim Mushalla Raudhtul Anwar.

Noor, Basran, dkk., (1993). Elite Muslim di Kalimantan Selatan (Studi Gerakan Elite Muslim di Bidang Pendidikan 1900-1950), Banjarmasin. Banjarmasin: Fakultas Tarbiyah IAIN Antasari.

Rahmadi, (2010). Jaringan Intelektual Ulama Banjar Abad XIX dan XX (Studi Proses, Pola dan Ekspansi Jaringan). Banjarmasin: Antasari Press.

Sarman, Imran, (1995). Pengajian Agama di Negara Kabupaten Hulu Sungai Selatan (1940-1995). Banjarmasin: Balai Penelitian IAIN Antasari.

Shiddiq, Abdurrahman. (t.th.). Risalah Amal Ma'rifah serta Taqrir. Banjarmasin: Toko Buku Mawaddah.

Sjamsuddin, Helius, (2007). Metodologi Sejarah. Yogyakarta: Penerbit Ombak.

Syukur, M. Asywadie, (1994). Pemikiran-Pemikiran Taubid Syekh Muhammad Sanusi. Surabaya: Bina Ilmu.

Syukur, M. Asywadie, (2009). Filsafat Tasawnf dan Aliran-alirannya. Banjarmasin: Antasari Press.

Tim Sahabat, (2003). Manakib Syekh Muhammad Nafis dan Ajarannya. Kandangan: Toko Sahabat.

Usman, A. Ghazali, (1999). Manaqib al-Mukarram al-Allamah Tuan Guru Syekh Salman al-Farisi 1279-1350 H/1857-1928 M. Tapin: Pemerintah Daerah Tk II Kabupaten Tapin. 
Van Bruinessen, (1999). Martin, Kitab Kuning, Pesantren dan Tareka: Tradisitradisi Islam di Indonesia. Bandung: Mizan.

Zaini, Muhammad, (1996). Risalat an Nuraniyyah fi Syarh al-Tawassulat alSammaniyyah. Banjar Baru: Matbaat al-Raudhah. 